Historic, Archive Document

Do not assume content reflects current scientific knowledge, policies, or practices. 



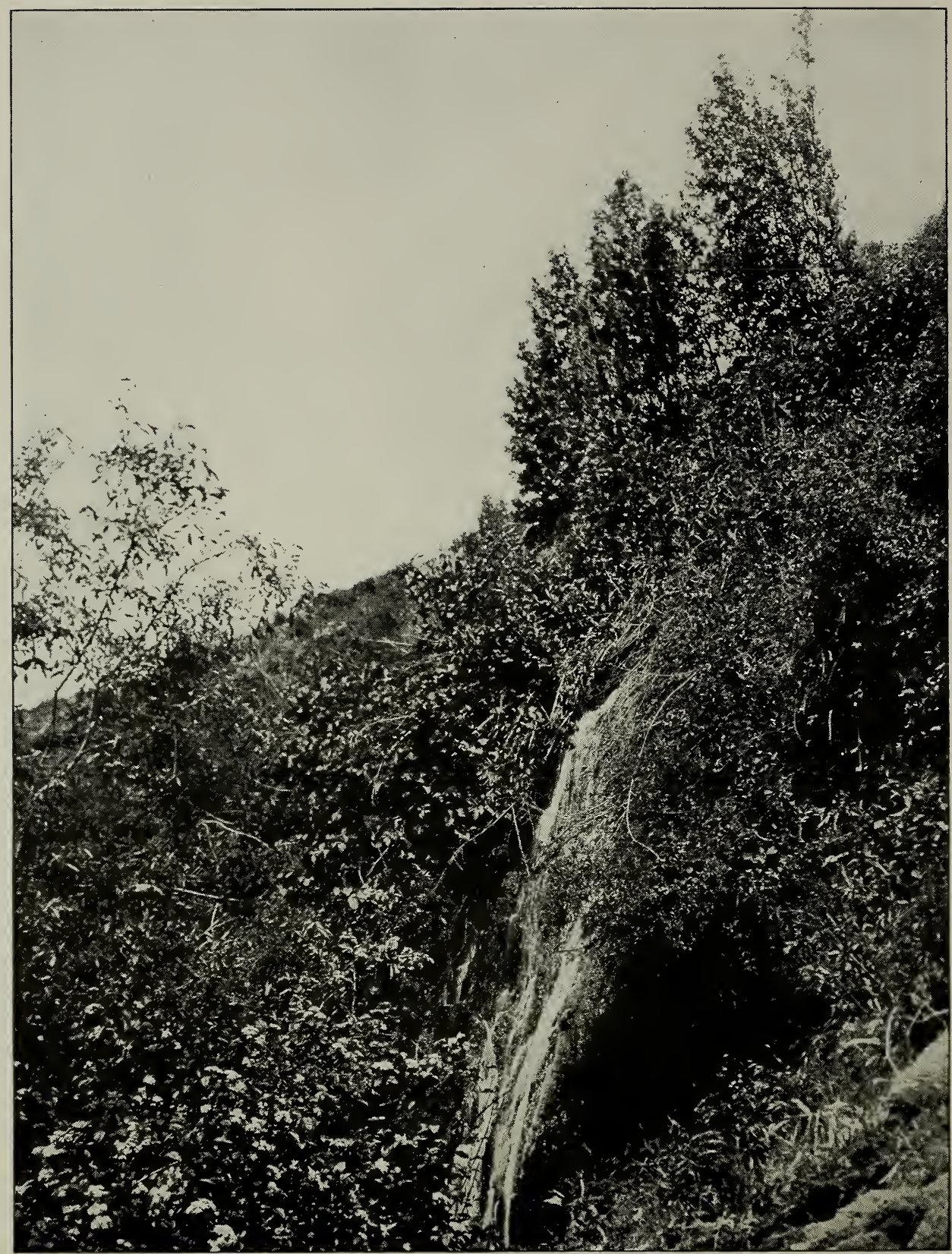

ONE OF THE HILLSIDE GARDENS AT "THE TERRACES"

At "The Terraces," a favorable climate, an abundance of water, and a wonderfully wide variety of soils and exposures combine to make an ideal garden spot, while, from the scenic standpoint, it is probably the most unique garden in the world. While I use terraces in my hillside gardening, "The Terraces" themselves are natural. Large springs feed a stream which flows down a little vale in the face of a high mountain range. Perhaps a quarter of a mile from their source they tumble over a limestone bluff to another level then again and again to other terraces until four have been passed.

The bluffs are from 50 to 70 feet each in height, and on their face is a succession of cascades and waterfalls. The gardens occupy all of the valley, the slopes and the successive terraces, while every nook and corner is utilized for the naturalization of colonies of ferns, lilies or other plants. 


\section{Purdy's Bulbs for Fall Planting}

CARL PURDY, UKIAH, CAL.

\section{Terms of Business}

Cash. Unless otherwise arranged, money must accompany the order.

Remittances under \$I can be made in stamps; over that amount money orders or checks are preferable.

Postage, Expressage or Freight will be prepaid by me without cost to customer. Where there are express offices, I generally use that method of shipping.

Safe Carriage Guaranteed, I guarantee that bulbs shall reach my customers in good order and shall be of good quality. If they are not, the money will be refunded; but claims for damages must be made immediately upon arrival of goods.

Quality of Bulbs. My bulbs are as good as can be bought in America. The Daffodils and Gladioli are grown at The Terraces, and my gardens are famous. My Tulips and Hyacinths are supplied by a firm in Holland who are known as specialists in the very best bulbs. They will outweigh and outsize any others on the market and have given my customers the very best satisfaction. No better bulbs can be bought.

Dates of Shipment. Daffodils are ready by September I. My importations of Tulips, Hyacinths and Spanish and English Irises will arrive in early October. Japanese Irises are grown at The Terraces and are ready any time after September I. It is better, however, both for the planter and myself, that all bulbs be sent in one shipment. There is no advantage whatever in out-of-door planting in California before the first rains which usually come late in October or early in November. Here where we know the nature of each bulb they can be kept in better condition than at the homes of customers a waiting the best planting time.

Order Early. Orders will be filled in the order of receipt, and certain varieties may be sold out if orders are too long delayed.

Large Quantities can be supplied at a reduced rate. Send list of requirements.

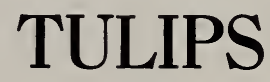

Of all bulbous plants, the Tulips are most showy, and it is worth much trouble to have them at their.best. In pots they can be had by midwinter, while in beds they are at their best from March to May. The methods of culture used in the East and Europe are not adapted to California, and will seldom produce good results; but, by studying the peculiarities of our climate, very fine flowers can be grown with little trouble.

\section{Culture of Tulips in California}

Situation of the Bed. Throughout California quite warm spells are to be expected in February or early March, and if the bed is exposed to the sun the bulbs will be forced into a premature bloom with very short stems. To guard against this, choose a situation which is shaded

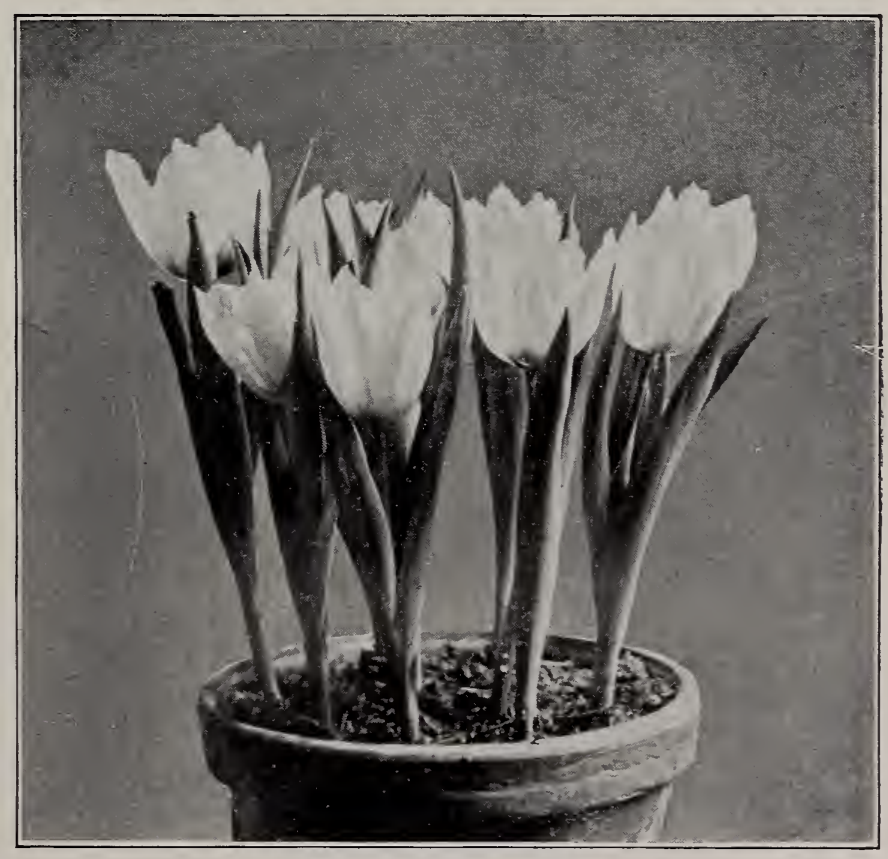

SINGLE TULIPS IN POT 


\section{TULIPS, continued}

at least one-third of the day, but half the day is better. The northeastern or northwestern corner of a building is best, but trees will give the same shelter. The bed must not be where sharp winds may reach it.

Soil. Tulips prefer a light, well-drained soil, but can be grown well in any soil that is not mucky. If the soil is heavy, it should be underdrained with tiles, gravel or any other porous conductor, and had better be raised 6 inches.

Manure should be used, well-rotted cow-manure being the best. It may be spread on the surface an inch thick and dug in, or, better yet, applied as indicated below.

Distance Apart and Depth to Plant. Tulips will do well when planted 3 inches apart

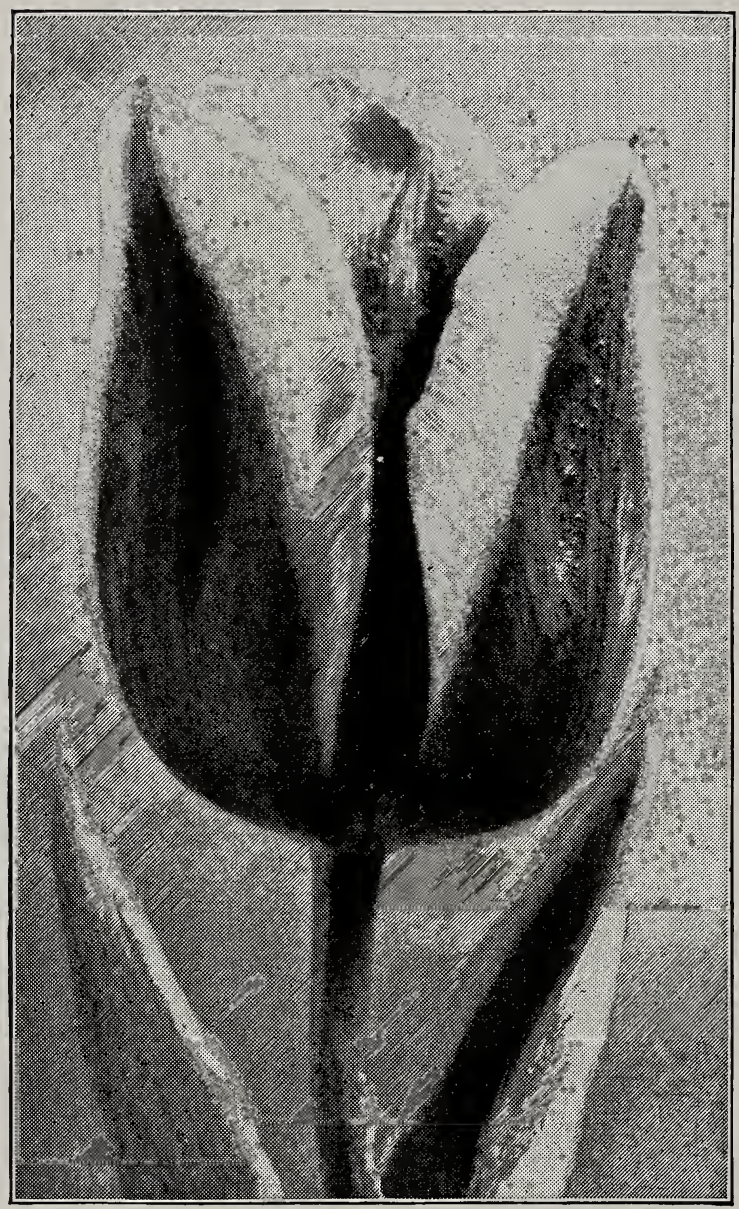

KEIZERKROON TULIP. One of the best for pots (see p. 4) each way, or sixteen to the square foot. The standard distance is 4 inches apart each way, or nine to the square foot. It is a waste of space to give them more.

Fancy Beds are to be avoided. They are only fit for open spaces and in California it is foolish to attempt them. A bed 3 to 4 feet wide, where the best situation can be given is much better, and it is also better to plant in wide variety so as to prolong the season, and to aim to have fine flowers for cutting rather than to produce a mass effect.

Shade. The best shade is one that is continually shifting so that the beds are in the sun a while and in the shade for a time. This is best obtained by watching the shadows of trees which are not closely planted or often still better by giving the outer shade of deciduous trees which are not too dense and through whose branches the lights play and change.

Mulching. A mulch of rotted manure put on in the spring before the tulips are through the ground is a most excellent thing. It keeps the ground from being packed and holds moisture to the top. It should not be of new or wet manure but of manure that is fairly well rotted and which can be spread neatly over the bed with a rake.

Plant Early. By this I do not mean August or September, as I have found no advantage whatever in having the bulbs in before the period of rains and cooler weather. Mid-October is the best time, November about as good, but further delay will be at the expense of the flowers. By no means plant later than January $\mathrm{I}$.

Method of Planting. The best method is that used in the great fields in Holland, where they are grown by millions. First, thoroughly spade and pulverize the soil and give drainage if it is needed. Then throw out the soil from a section of the bed to the depth of 7 inches. Put in a layer of manure an inch deep and cover with an inch and a half of soil. Set your bulbs 3 or 4 inches apart each way, and then cover them gently with the soil from a second section of the bed. Proceed in this way until the bed is planted, and then level with the remaining soil. As the bulbs are about 2 inches high, this will give them a cover of about 3 inches of soil. While well-rotted manure is prefer- 


\section{TULIPS, continued}

able, any manure can be used that has gone through the first heating. In cold soils, plant an inch shallower. If the soil is heavy, and sharp sand is obtainable, put some around the bulbs.

Watering. During the winter and early spring, give only enough water to keep the bed moist; usually the rain is ample. As soon as the flower-bud appears, water liberally until a few weeks after the flowering is over and then dry them off. As soon as the leaves are dry, dig the bulbs and store in any dry, airy place until planting time the next fall. The lighter the soils, the more water is needed during the flowering season.

Digging the Bulbs When Ripe. A Tulip is ripe when the leaves turn yellow. There is no need to wait until they are entirely dry. Late Tulips can be left in the ground from year to year yet this is not the best practice, as they form many offsets and soon become crowded so that the bulbs have not enough room to do their best. Then the roots of trees and shrubs are apt to encroach on the bed, and annual planting allows one to cut them in. Still again the soil must be annually enriched if the best results are to be had, and the cultivation to a good depth is a distinct advantage.

Method of Storing. It is not necessary to put the bulbs in sand or any other packing material. All that is needed is to put them in bags or boxes in a dry place and leave them there until proper planting time.

Gophers. Like the poor they are always with us, and they like Tulips. They can be trapped with the right trap and patience. In my gardens, with a frontage of a mile, we control them by trapping. It is hard to poison them in a garden because there is so much good food, and they store away by far the greater part of what they take. Some soft food like carrots, parsnips, green corn or raisins with a little strychnine in it is the best method of poisoning.

Gopher Fences. For years I have thought of some cheap way of fencing them out and have at last found it. I use wire mesh described in catalogues as $1 / 2$-inch mesh poultry fence, 30 inches high.

A ditch 30 inches deep is dug, the netting stood upright in it and the soil then worked down on both sides and packed. A gopher very seldom goes below this depth. Almost as seldom do

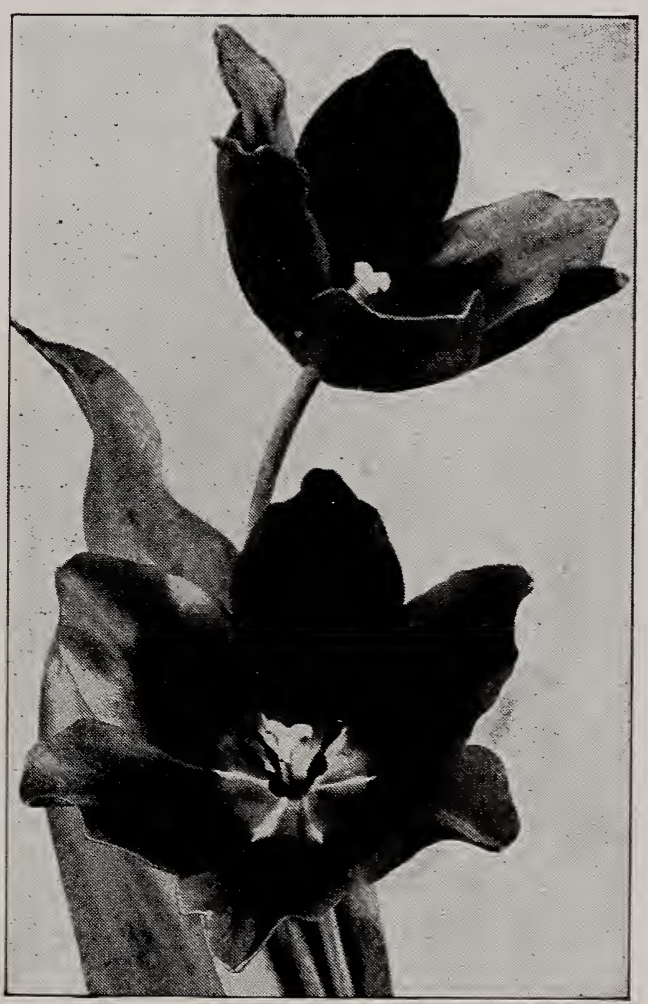

GESNERIANA TULIPS (see page 5) they run along the top of the ground as a rat would seeking a new home. For most purposes the gopher fence answers well.

Tulips in Boxes. If gophers are numerous, the bulbs can be planted in boxes 8 inches deep, with soil as indicated. The boxes should be in a half-shaded place and watered liberally, even in winter.

Tulips in Pots for Winter Bloom. The best time to pot is in early fall. The best soil for potting is a compost of two parts of garden loam to one part of well-rotted cow manure and one part sharp sand. Use a 5- or 6-inch pot, and first put in some broken pieces of crock with a little loose material to insure good drainage. For a 5-inch pot, use three to five bulbs, and for a 6-inch pot, four to seven. Plant so that the tip of the bulb projects, and water moderately. Put in a cool, dark place for five or six weeks until they are well rooted. This can be told by gently striking the side of the pot until the soil will slip out. If the pot is filled with a mass of roots, the bulbs are ready to bring to the light. Water moderately, and do not give full sunlight, but let them come on slowly in a window or cool greenhouse.

The Best Varieties to Pot. Any early single Tulip will do. Chrysolora, Cottage Maid and Keizerkroon are especially fine. Late Tulips seldom do well in pots. 


\section{Early Single Tulips}

These are large and wonderfully brilliant flowers, with stems from 7 to $\mathrm{I} 4$ inches long when well grown. Do not plant these in a situation much exposed to the sun, or the flowers will come too soon, the stems will be very short and the effect poor. In California they must be planted in a shady situation or else shaded artificially when the buds start.

For Forcing or Pot Culture these are the only Tulips to use. I have selected the best forcing varieties, together with others which grow good stems when shaded. The height of finely grown plants is given in inches after each variety.

Each Doz. roo

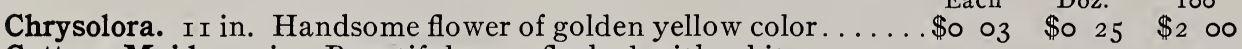

Cottage Maid. Io in. Beautiful rose, flushed with white.......... $\begin{aligned} & 03 \\ & 3\end{aligned} \begin{array}{rrr}25 & 25\end{array}$

Duchesse de Parma. I 3 in. A bright orange-scarlet, margined with gold. One of the best........................ $03 \quad 30 \quad 225$

Cramoisie Brilliant (Sparkler). I3 in. A wonderfully brilliant, rich

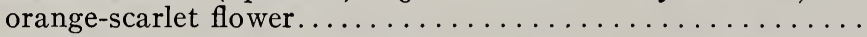

King of the Yellows. I 2 in. Large golden yellow flowers of globular

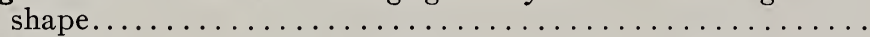

Keizerkroon. I4 in. Rich crimson-scarlet, edged bright yellow.

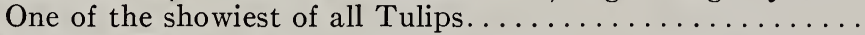

Pottebakker, White. I 2 in. A large, very fine, pure white flower. . Prince de Ligny. I 3 in. A very showy, rich yellow sort; exquisite. Prince of Austria. I3 in. Large, orange-scarlet flowers of unique shape. The ideal Tulip for forcing; sweet scented...........

Rembrandt. ${ }_{5}$ in. A dazzling scarlet, of unsurpassed brilliancy.

Thomas Moore. I6 in. A beautiful terra-cotta, flushed with gold. .

White Swan. I 5 in. A pure white flower which lasts wonderfully. I consider it the best white for California ................

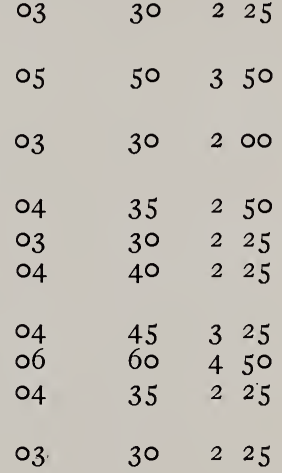

\section{Parrot Tulips}

This is a race of gorgeously colored Tulips of very large size, with the flowers fancifully cut and slashed in the oddest way. They have short stems and must be grown here like Early Single Tulips-with considerable light shade. Can be forced late without heat. Mixed bulbs, all colors. $3 \mathrm{cts}$. each, $30 \mathrm{cts}$. per doz.

\section{May-Flowering, or Cottage Tulips}

These splendid long-stemmed Tulips flower in California in late March and April. They can be grown to perfection if certain points are carefully observed. In exceptionally cool springs, they do well in the open sun, but it is safer to shade. The lath shade made of movable strips which can be adjusted according to the heat is the best possible shade. Next to that is the shade of deciduous trees. They give a constantly shifting shade, never very heavy at the flowering season of Tulips. A bed may be so planted that it catches the shade of different deciduous trees at intervals with periods of sunlight. The Tulips at my gardens at The Terraces are famous in California, and they are grown among groves of tall, young black oaks. These are not in leaf until mid-April, and the shade is light. They begin to leaf out as the flowers come into bloom, and, with liberal watering, I get wonderfully fine flowers.

Late Tulips can be planted in the border with perennial plants or low shrubs, but the places must be carefully marked so that they will not be injured in cultivating other things. I prefer separate beds and lifting every year. I offer some of the very best varieties.

\section{Collection of Late Tulips}

I will make a collection of these fine Tulips containing ten bulbs each, of my selection, or roo bulbs in all, for $\$ 2.25$ all named. This is wonderful value for these fine Tulips.

Bouton d'Or. I 7 in. A tall, stiff-stemmed, golden yellow Tulip, with black stamens in strong contrast. Very fine in the mass Each or for cutting............................... $0_{3}$

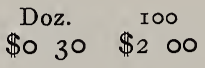

Bizarres. 24 in. Brownish flowers striped with lighter colors, and

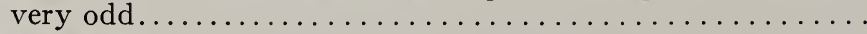

Bridesmaid. I 2 in. Rather short stemmed, with a cherry-red

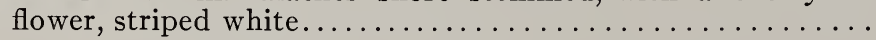

$\begin{array}{lll}03 & 25 & 200 \\ 03 & 30 & 2.00\end{array}$




\section{LATE TULIPS, continued}

Dame Elegante. 24 in. As elegant as its name implies. Tall, with a white flower lightly streaked scarlet. A beautiful flower. 5 cts. each, 50 cts. per doz., $\$_{3}$ per I00.

Fulgens. 24 in. Tall with long, pointed petals of an intense red. Very showy and the equal of Spathulata. 4 cts. each, 30 cts. per doz., $\$ 2.50$ per I00.

Gesneriana Major or Spathulata. 24 in. The best-known and most admired of all late Tulips. Tall, with large flowers with pointed petals, and of a fine scarlet, with blue-black centers. Plant by the hundreds for cutting. 3 cts. each, 30 cts. per doz., $\$ 2.25$ per 100 .

Golden Crown. 20 in. Large yellow flowers edged with crimson. To grow well it needs shade as the color fades in strong light; but well grown it is superb. 3 cts. each, 25 cts. per doz., $\$ 2$ per 100.

La Merveille. I 8 in. A wonderfully fine Tulip, changing from orange-red to a rare shade of red. Pointed petals and a large flower. 4 cts. each, 35 cts. per doz., $\$ 2.50$ per 100.

Macrospeila. I6 in. One of the varieties of Gesneriana, and as brilliant as Major, but a deeper red with black center. Very showy. 3 cts. each, 30 cts. per doz., $\$ 2.25$ per Ioo.

Parisian White, or La Candeur. I6 in. A little-known but very fine Tulip with flowers pure white when they first open but flushing with red as they age. Very fine for cutting. 5 cts. each, $50 \mathrm{cts}$. per doz., $\$_{3}$ per Ioo.

Parisian Yellow. 24 in. Tall and slender, with pointed petals

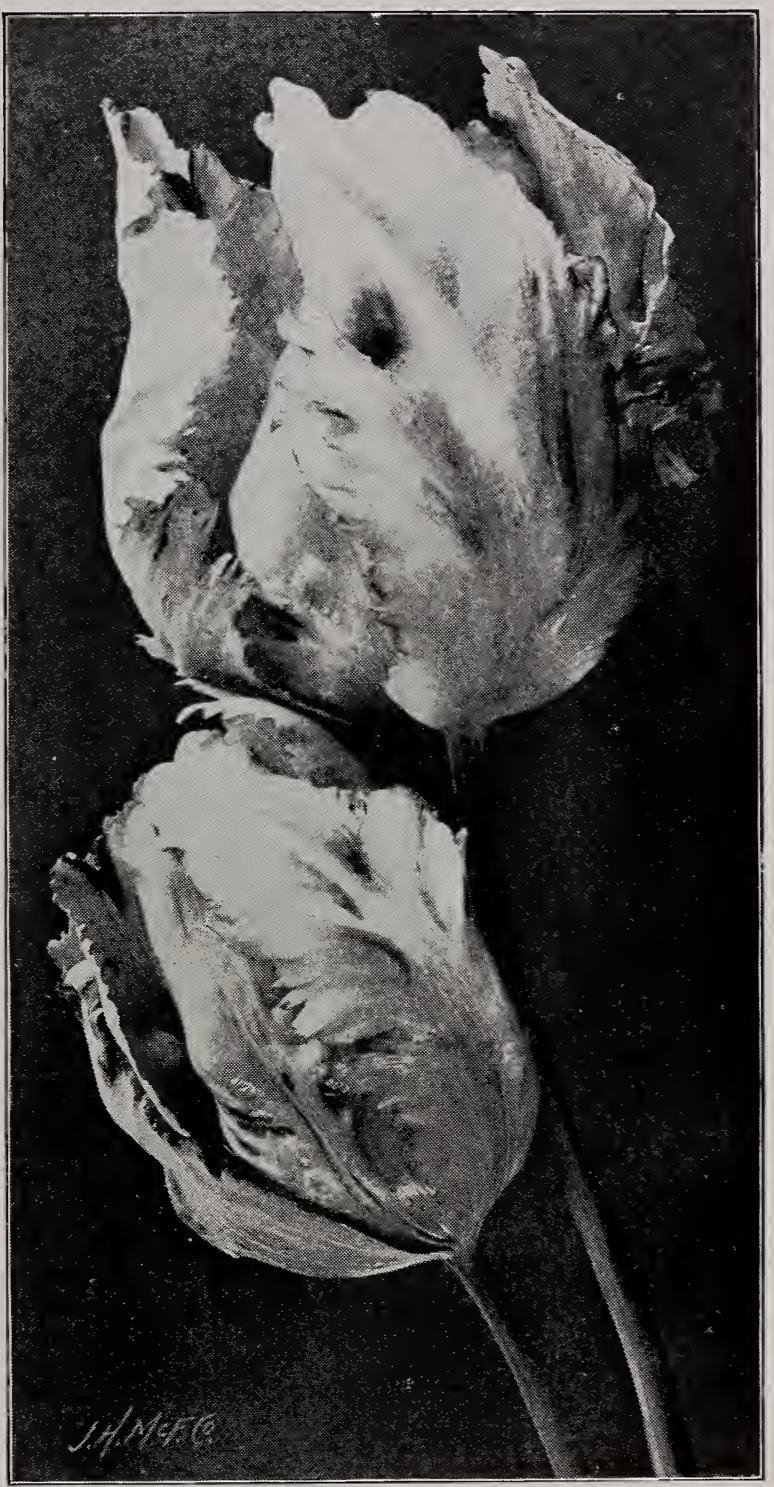

PARROT TULIPS (see page 4 ) of a fine lemon-yellow. Probably the best late yellow for cut- Each Doz. 100 ting. Where I sell a dozen one year I sell many dozens the succeeding year..................................... $0_{4}$ \$o $40 \quad \$ 275$

Picotee, or Maiden's Blush. I4 in. It opens white, tinged yellow, and becomes pure white, beautifully rayed with scarlet. A

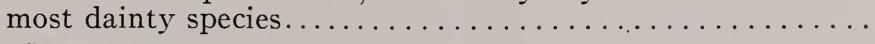

Retroflexa. I6 in. One of the prettiest of Tulips; of a rich light yellow, and with long, pointed petals which curve back...... 


\section{Giant Darwin Tulips}

See the Illustration on front cover

The Darwin Tulips are a class of May-flowering Tulips by themselves, and in their grand flowers with long stout stems, and their wonderful variety of coloring they are unsurpassed. Their keeping qualities either in the bed or when cut is unusual. Even in the full sun they last long in the beds. They should have light shifting shade (see page 2) and be watered very liberally as soon as the buds show-not merely a daily sprinkling but frequent soakings. I also use nitrate of soda at this time, sprinkling it on the beds and washing it in by sprinkling.

The mulch of old manure recommended on page 2 is also a fine thing.

On these points and the careful planting and manuring as directed for all Tulips depends the securing of such flowers as they are capable of. At first the flowers form an incurved cup. This widens day after day until the petals spread almost flat. In the open-cup stage, hundreds of my flowers are from $3 \frac{1}{2}$ to 5 inches across, and, when spread, as wide as ro inches. The heights given after the names are of well-grown plants.

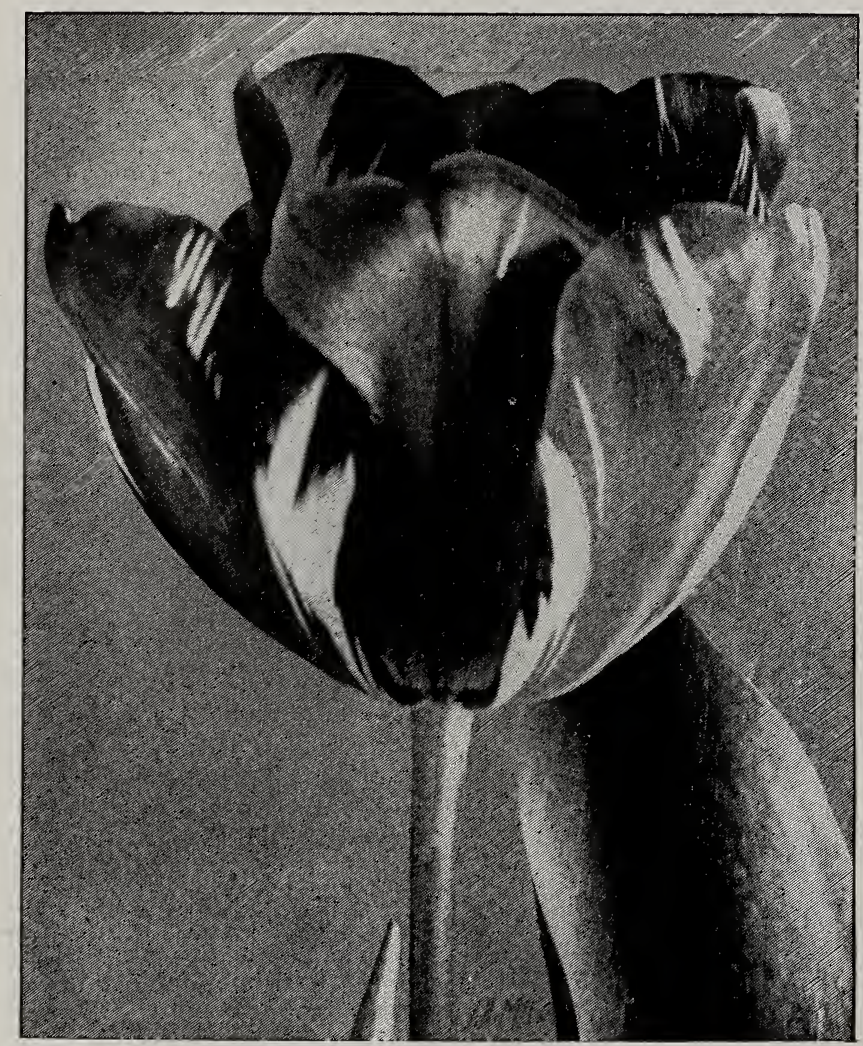

REMBRANDT TULIP (see page 7)

\section{Named Darwin Tulips}

In the set of Darwin Tulips following, every one is tall with large flowers of fine shape and superb coloring. The most expensive varieties to be found in any other catalogue will not average finer varieties or colors. I place all at the low price of $\mathbf{5}$ cts. each, 50 cts. per doz., $\$ 3.50$ per roo, except where noted; and, as this includes delivery, it is the best value in this line offered in America.

In white, Painted Lady, a creamy white, and Wedding Veil, pure white.

In soft pink, Calliope and Baronne de la Tonnaye; both superb.

In soft blush-pink, Gretchen or Margaret, exceeded by none in delicacy.

In brilliant rose, Gustave Dore and Lenotre, both very fine.

In glowing scarlet, Glory and Orion, both extra fine. 
NAMED $\mathrm{i} D A R W I N$ TULIPS, con.

In glowing! dark red, Pieneman and Ripperda, superb.

In deep velvety brown, Red Donders is one of the prime favorites.

If almost black is wished, Cetewayo and Fra Angelico, grand flowers both.!

In blue, Bleu Celeste, but at $7 \mathrm{cts}$. each, 75 cts. per doz.

In soft heliotrope-lilac none excel Circe and Rev. H. Cobank, but the latter is $7 \mathrm{cts}$. each, $75 \mathrm{cts}$. per doz., \$6 per Io०.

In lavender-blue I offer the very fine Goliath and in the darker violet the superfine Archimedes.

In still darker violet, approaching brown, Auber.

In reddish black, Von Jehring is very nearly black, and a splendid color.

In reddish lilac, Palissa is not 'excelled.

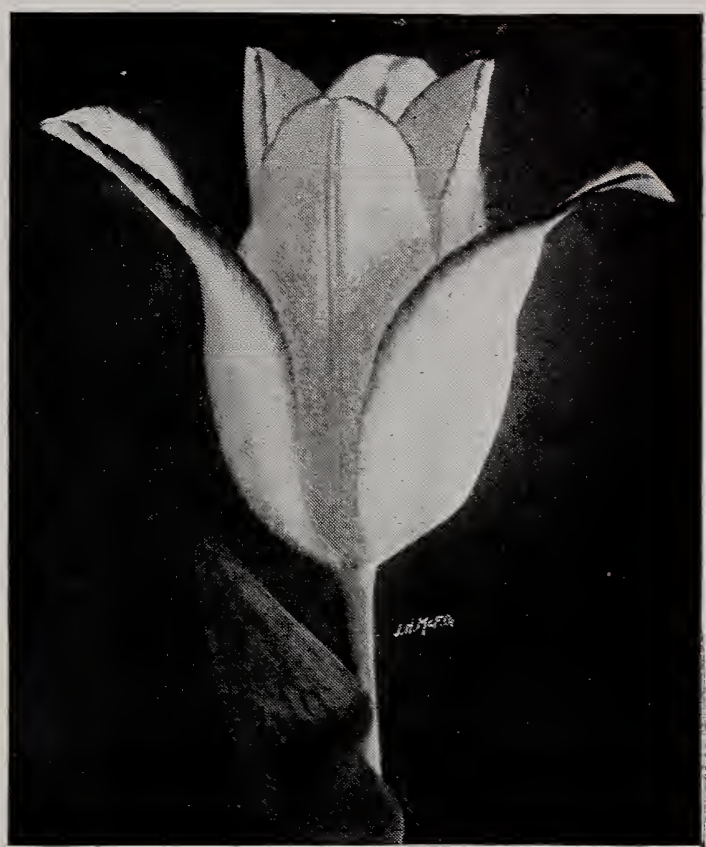

PICOTEE TULIP (see page 5)

\section{Superb Collections of Fine Named Darwin Tulips}

My grower in Holland puts up very fine collections of Named Darwin Tulips. He gives a wide range of colors, very fine varieties, and large bulbs. Better value cannot be given for the money. Bought separately, they would cost far more.

Collection of ro very fine sorts, Io each, Ioo bulbs, for $\$ 2.75$. One each of same, not named, ro bulbs, 35 cts.

Collection of 25 varieties, 5 each, 125 bulbs, for $\$ 4.50$. One each of same, Enot $_{\text {n }}$ named, for $\$$.

\section{Fine Mixed Darwin Tulips}

I can supply a fine mixture at $\$ 2$ per Ioo. I recommend the use of the named collections, however.

\section{Rembrandt Tulips}

These belong to the same race as the Darwin Tulips and are most magnificent flowers, wonderfully striped and splashed and in light colors. Mixed bulbs 60 cts. per doz.

\section{DAFFODILS}

These splendid spring-flowering bulbs have been highly esteemed in Europe for many years and are yearly growing in favor in America. You couldn't possibly plant too many of them. They are perfectly hardy, are more easily grown than onions or turnips, need hardly any watering and positively no care after they have flowered, and are not troubled by rats or gophers. They give a liberal bloom when flowers are most prized, in early spring, and for cut-flowers are unexcelled. Plant a few dozen if you can do no more, hundreds if you can, and if your purse will allow you to plant beds of thousands, you can rest assured that you can buy no spring-blooming bulbs which will give a greater return in satisfaction. I grow many Daffodils and my customers say that they cannot get better ones elsewhere.

I can highly recommend my entire assortment. It was selected with the aid of the first Daffodil growers of the world, and even then I have dropped many varieties that I have tested. 


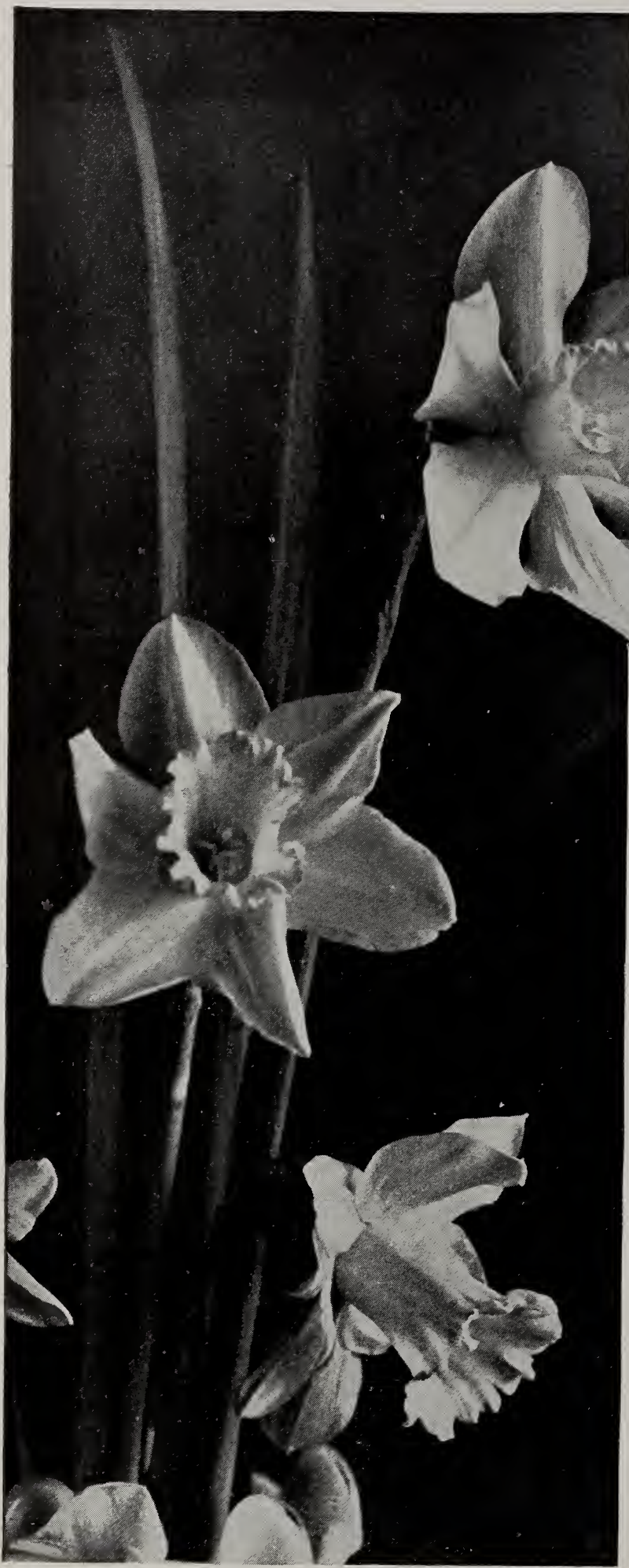

SIR WATKINS DAFFODILS (see page Io)

\section{Culture of Daffodils}

My observation is that, in California, Daffodils will grow in any soil from sand to the stickiest adobe. The soil which best suits them is a rich loam with abundant moisture during the winter and which gets dry in the summer.

Dig the ground up deeply and thoroughly and then let it settle a few weeks before planting. Do not use fresh stable manure, although if manure has been applied the year before it will do no injury. The best fertilizer available here in California is crushed bone, at the rate of one and one-half ounces to the square yard. With this sulphate of potash can be used at the rate of threefourths ounce per square yard. Daffodils are especially fond of lime, and a sprinkling of quicklime on the soil before it is dug is of advantage.

Planting and Lifting. The best time to plant is with the first rains, although little difference will be noticed in planting up to November I; but after that date the bu'bs lose by being out of the ground, and planting later than January $I$ is apt to give poor results. The bulbs may be left undisturbed for years, but it is my observation that it is better to lift them and reset every second year, and, with the exception of the various forms of Poeticus, there is some gain in lifting every year and replanting at once. The bulbs produce offsets, and, having to share the space with their offspring, become too crowded in three years to do well. By all means plant the Poeticus varieties with liberal space, and do not move until crowding makes it necessary. They are far finer when undisturbed. 


\section{DAFFODILS, continued}

Depth to Plant. The average depth to plant is from 2 to 3 inches. Better less than more. A safe rule is to cover one and a half times their height.

Shade. All Daffodils prefer light shade. In California we should select a cool situation if the soil is light, and much finer and longer stems will be had when they are shaded from one-fourth to one-half the day. This does not mean that the bulbs will not thrive quite as well in sun as in shade, but as long stems are very desirable, the shady situation is much better. Excellent results can be had by planting Daffodils in groups among shrubs or hardy perennials.

Watering. Daffodils like much water when growing. If the ground is kept all but wet until after blooming time, they will be all the better.

\section{Narcissus, Daffodils, Jonquils}

I am so often questioned as to the difference

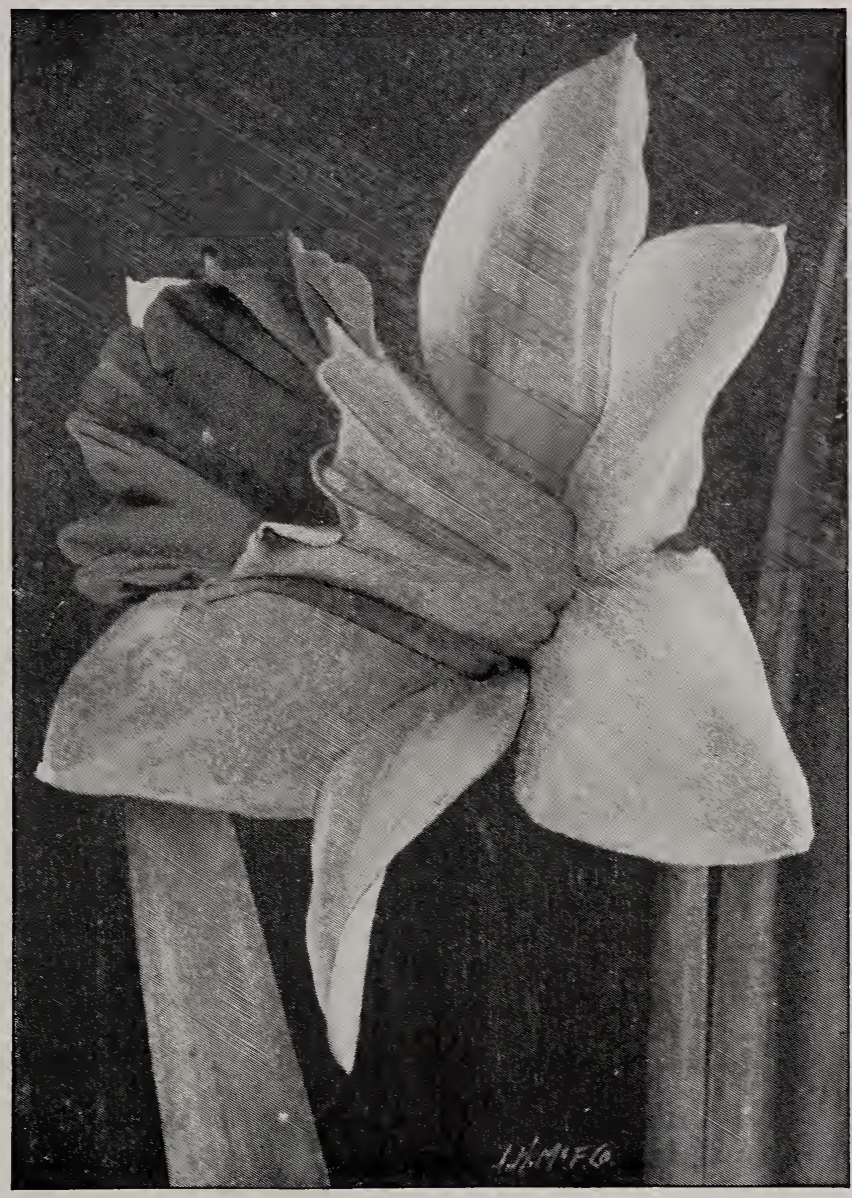

GLORY OF LEYDEN between Daffodils, Narcissi and Jonquils, that I take this opportunity to explain. Narcissus is the botanical name of all of the plants of this group whether they have large flowers with trumpets like Emperor or Golden Spur, small flowers like the Poeticus, or two or more flowers on a stem as in the Jonquils, the Chinese Lilies and their European sisters.

All are Narcissi alike.

A Narcissus with a single flower on a stem, whether with large or small trumpet, is a Daffodil. Jonquils are Narcissi with two or three shallow cupped flowers of a pleasing yellow and quite fragrant. The name Jonquils comes from Juncus, or rushes, because the leaves resemble that plant. Polyanthus Narcissi are all of the sorts which, like the Chinese Sacred Lily, have the flowers in bunches.

\section{Daffodils with Long Trumpets}

Emperor. A grand, rich yellow flower. One of the best....... Each Doz. 100

Empress. As fine as the above, but with trumpet pure white and the

cup rich yellow. Daffodils colored in this way are called Bicolors,

and Empress is one of the best of that class.............. $0_{5} \quad 50 \quad 350$

Excelsior. A golden yellow, large and fine.............. ० 70

Glory of Leyden. Much larger than Emperor and a deep yellow... I 5 I 50

Golden Spur. Smaller than Emperor, and of a very fine, deep yellow. $04 \quad 40$

Victoria. Like Empress in color, but a broader trumpet. Fine... o6 60 


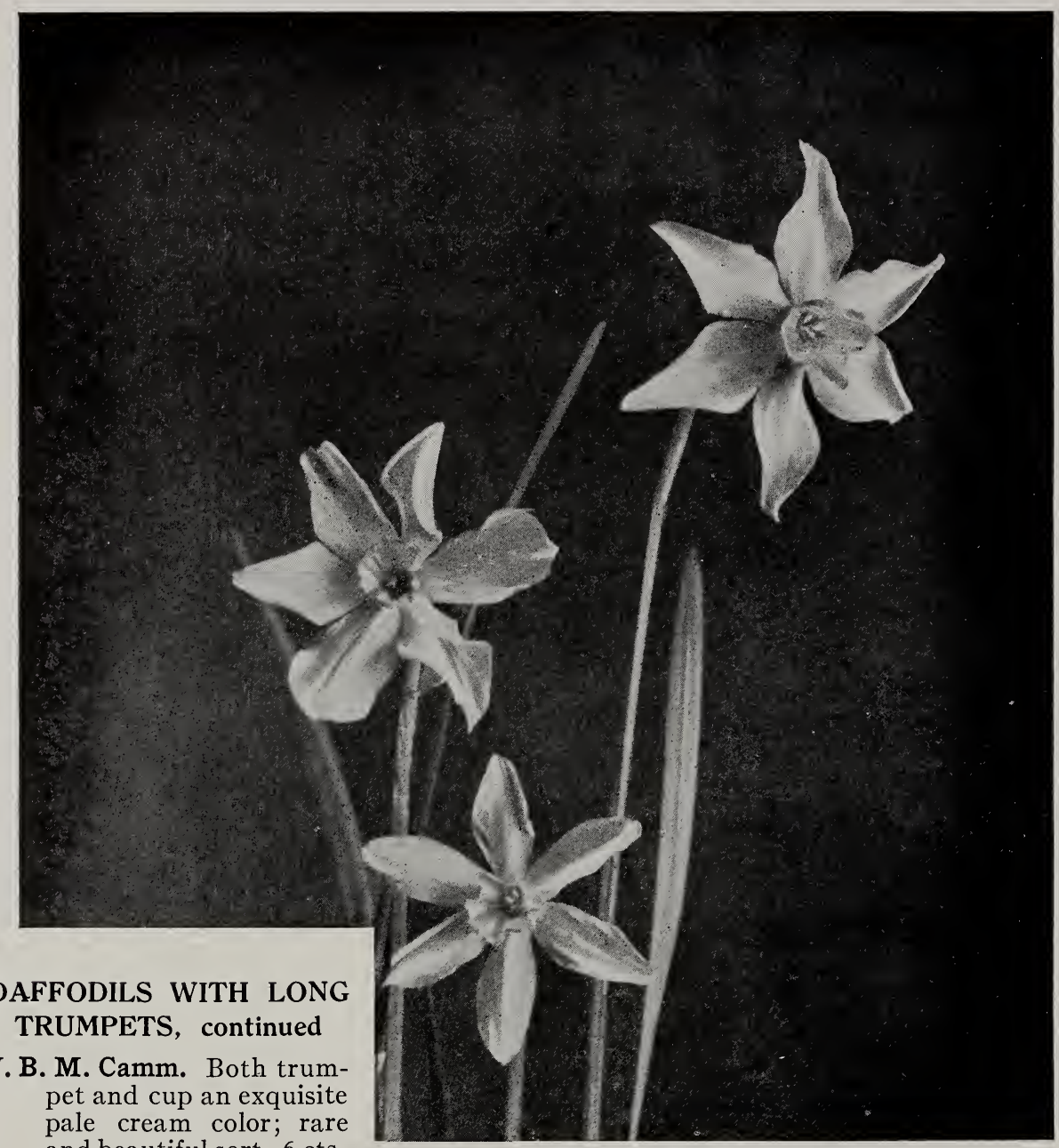
pale cream color; rare each, $60 \mathrm{cts}$. per doz.

BARRI CONSPICUUS DAFFODILS

William Goldring. Much smaller than any of the preceding, with a graceful white flower. Called The Swan's Neck Daffodil. 5 cts. each, 50 cts. per doz.

\section{Daffodils with Cup-Shaped Trumpets}

Barri conspicuus. This long-stemmed variety has a light canary- Each yellow flower, with a cup rimmed with scarlet. It is a beauty. \$o 03

Cynosure. Good-sized yellow flowers with the cup edged scarlet.. ०3

Duchess of Westminster. Perianth pure white, cup yellow, but becoming white............................ 10

Doz. $\quad$ I00

\$o 25 \$I 50

25 I 50

I $00 \quad 800$

Stella Superba. A large, star-shaped flower, with white perianth and bright yellow cup. Stella is a nice flower, but this is by far its superior. It has splendid keeping qualities.............. 05

Sir Watkin. The Welsh Giant. A grand flower, sometimes $51 / 2$ inches across. Light yellow, with the cup tinted orange. None better. 04

Frank Miles. An exquisite variety, with yellow, twisted petals..... ०3

Mrs. Langtry. A flower of medium size, at first a rich, creamy white, but becoming pure white, and beautifully formed........ O2 $_{2}$

Katherine Spurrell. A tall, fully rounded flower, of perfect form and satiny texture. Pure white. I know of none more lovely...... o6

C. J. Backhouse. A little under size, with a slender trumpet; nearly scarlet in color, and the perianth yellow. It is a striking form. . 04 


\section{Jonquils and Poet's Narcissus}

In these classes the perianth is fully rounded, but the trumpet is so small as to be a very shallow cup. They are much smaller than the other classes, but with long stems and a dainty beauty that makes them great favorites.

Poet's Narcissus. The old Poeticus of the gardens. A fine plant, Each Doz. roo with a tall stem and pure white flowers, with a rich scarlet cup,

and are very fragrant. Not sure bloomers................ $0_{2}$ \$o I $_{5}$ \$o 75

Ornatus. This is a form of the Poet's Narcissus, with very fine, white flowers and yellow cup, tinged scarlet. They flower very freely and early, and cannot be planted too widely............. 02

Poetaz Elvira. This is a hybrid between the last and the Chinese Sacred Lily. It has several fine, pale yellow flowers, of fine size, and blooms profusely. A fine thing.................. o6 60

Jonquils. These have several flowers on the stem, are a rich yellow and have a very pleasing fragrance. There is a small-flowered sort usually sold under the name Campernelles and the large fine variety I offer, called Jonquil rugulosus, which is far better. 2 cts. each, $20 \mathrm{cts}$. per doz., \$1.50 per Ioo.

\section{Double Daffodils}

Each Doz. Ioo

Von Sion. Very double, deep yellow flowers............. \$o 05 \$o 40 \$3

$\begin{array}{lllll}\text { Sulphur Crown. A splendid double sort, of sulphur-yellow color ... } 06 & 60 & & \\ \text { Double Poet's. Very double, white and very fragrant........... } & 03 & 25 & \text { I } 25\end{array}$

\section{Mixed Daffodils}

In a large garden, bulbs will get mixed, and often the finest sorts are among the accidental mixtures. My Mixed Daffodils are a most unusual bargain. 30 cts. per doz., \$I.50 per I00, \$1 2.50 per I,000.

\section{Daffodils for Naturalizing}

While all sorts will grow in this way, the smaller-flowered sorts look more in keeping. The great trumpets like Emperor and Empress do not look wild enough, but the Barri conspicuus, Cynosure, Poeticus, and even the small, rich, yellow trumpets of Obvallaris look as if they belonged there. I offer good bulbs for the purpose, not the largest, but giving excellent flowers and all of flowering size.

Sir Watkin. \$2 per 100, \$1 5 per I,000.

Barri conspicuus. \$I per I00, $\$ 8$ per I $, 000, \$ 60$ per I0,000.

Poeticus of the Gardens. 60 cts. per I $00, \$ 5$ per I,000, $\$ 40$ per Io,000.

Poeticus ornatus. $80 \mathrm{cts}$. per 100, $\$ 7$ per $\mathrm{I}, 000$.

Cynosure. $90 \mathrm{cts}$. per I00, $\$ 7.50$ per $\mathrm{I}, 000$.

Obvallaris. A golden yellow, small trumpet very effective in grass. \$1.25 per roo, \$10 per I,000.

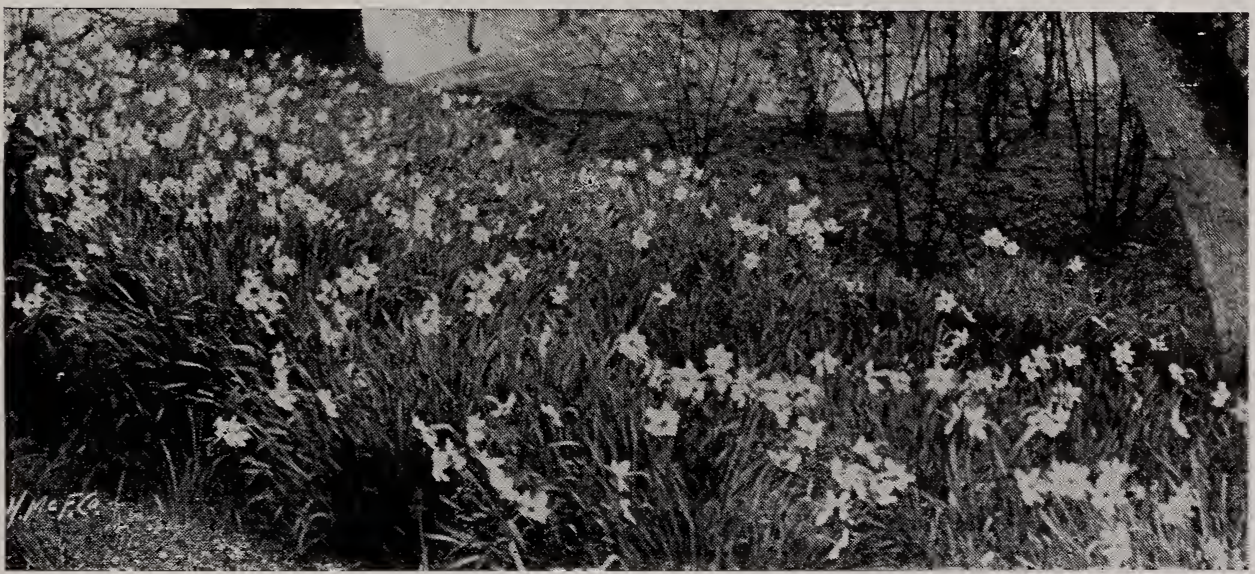

NARCISSUS POETICUS, naturalized 


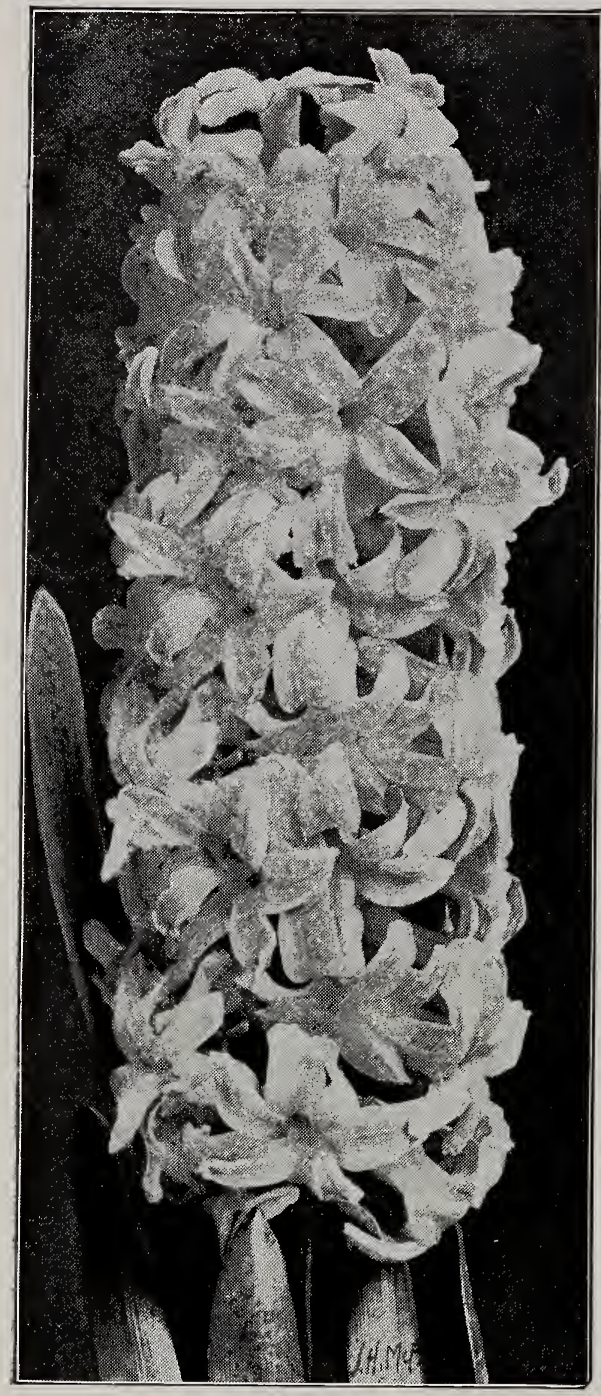

SINGLE HYACINTH

\section{HYACINTHS}

No winter-flowering bulbs are more esteemed than these. They can be grown very easily in pots in the soil and manner given for tulips, but using a single bulb to a 5 -inch pot. They can be grown out-of-doors in the same manner as tulips, but I would not recommend this. All Hyacinth bulbs are especially grown for forcing and will never give the same bloom a second year. If you wish fine Hyacinths, you must buy new bulbs each season.

I am offering very fine bulbs of two grades. The first size are what are known as exhibition bulbs, and will produce from one to three large spikes. These are very large, heavy bulbs. The second size are fine, solid bulbs, which will produce a single spike quite good enough for any one.

First-size bulbs, 12c. each, $\$ 1.20$ per doz.; second-size bulbs, $8 \mathrm{c}$. each, $80 \mathrm{c}$. per doz.

In pure white I offer Baroness van Thuyll, in single, and La Virginite in double.

In white, tinged pink, Mr. Plimsoll, single.

In red, Gertrude, with pretty bells in carmine-rose, and Robert Steiger in deep iose; both single, and the blush-pink Grootvoorst in double.

In blues I offer King of the Blues. Glossy indigo-blue; Marie in purple shaded, Captain Boyton in light blue; all singles; and in double, Garrick, in light blue.

In yellow, Ida in canary-yellow, and King of the Yellows in deep yellow; both single.

\section{Smaller Hyacinths for Planting in Beds}

These will produce good flowers, very satisfactory, but no such spires can be expected as from exhibition or first-size bulbs. Pure White, Dark Red, Rose-red or Pink, Dark Blue, Light Blue. All of these at 50 cts. per doz., \$4 per Ioo.

\section{GERMAN IRIS}

These are the Flag Lilies or Fleur de Lis of the old gardens, and a more hardy, grateful or satisfactory bulb cannot be planted. Even when neglected they will stand any sort of hardship and flower for years; but, given a well-drained situation and any good soil, heavy or light, and divided in late summer every second year, they will give more for the care bestowed upon them than any other bulbous plant. (See 4 th cover.)

I have unnamed bulbs in either white, light blue, purple or yellow with blue outsides. These at Io cts. each, \$I per doz., $\$ 6$ per Ioo. If you wish the rarer things in this line, I can offer smaller imported bulbs at same price in twenty-five varieties, not less than three of a sort.

\section{SPANISH IRIS}

These very attractive bulbous plants are of great value for either bedding or cutflowers. Give much the same treatment as for tulips, using less manure. If the soil is rather moist and loamy, they do better. They will grow on and flower liberally for years.

Fine Mixed Bulb. Doz. I00 1,000

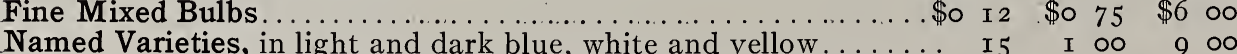




\section{JAPANESE IRIS}

This magnificent race of perennial plants cannot be surpassed in their season for varied beauty of enormous flowers. They begin blooming in June and flower for five or six weeks. Many of the flowers measure ro to $\mathrm{r} 2$ inches across with stems as high as 40 inches. To grow such flowers takes care. They are generally considered bog plants, and do well on the edge of ponds, running streams or ditches in deep, rich soil. They will also grow under several inches of water. Such situations are not necessary, but very heavy feeding and plenty of water during the growing season are. I have seen the Japs grow them wonderfully well on dry hills, as follows: Soil, heavy clay. Plants in rows $3 \frac{1}{2}$ feet across and a foot apart in the row; the plants about 3 inches above the trough between the rows. In early spring, barnyard manure is spread between the rows about 6 inches deep, and at frequent intervals this is watered with a hose, thus washing the liquid manure to the roots of the Irises. The manure also forms a mulch. They also give a dressing of nitrate of soda and bone meal when planting. The results are very fine even if the soil is light and poor.

Named Strong Plants, 25 cts. each, \$2 per doz., \$1 5 per Ioo.

\section{OTHER IRISES}

ENGLISH IRIS. These are larger than Spanish Irises, similar in growth and needs, and in rich shades of blue, purple and white. Mixed Bulbs. 40 cts. per doz., \$3 per roo.

IRIS OCHROLEUCA (Orientalis gigantea). This is a tall Iris which grows well in any garden soil and produces many creamy white flowers on stems 3 or 4 feet high. 25 cts. each, $\$ 2.50$ per doz.

IRIS SUSIANA. A very fine bulbous Iris flowering in May. The large flowers are blush colored and tinted with brown and covered with a network of dark lines at once unique and most beautiful. Worth every one's while. I 5 cts. each, \$r.50 per doz.

IRIS SIBIRICA. Most beautiful small rhizomatous rooted 'bulbs and among the first to flower in the spring. 5 cts. each, 4 oc. per doz.

\section{GLADIOLUS}

Gladioli thrive in a wide variety of soils, but prefer a fairly rich sandy loam. There are two classes.

\section{CLASS I}

These must be planted in the fall like narcissus. The Bride. Early flowering and pure white. A very fine cut-flower. 2 cts. each, 20 cts. per doz., \$1.25 per roo.

Blushing Bride. Same, with rosy blush. 2 cts. each, 20 cts. per doz., $\$ 1.25$ per 100 .

Colvillei. This is a red "Bride". 3 cts. each, 25 cts. per doz., \$I.5० per 100.

Gladiolus nanus. Earlyflowering, in fine mixture. 4 cts. each, 40 cts. per doz.

Gladiolus ramosus. In fine mixture, same as last. $4 \mathrm{cts}$. each, $40 \mathrm{cts}$. per doz., $\$ 3$ per too.

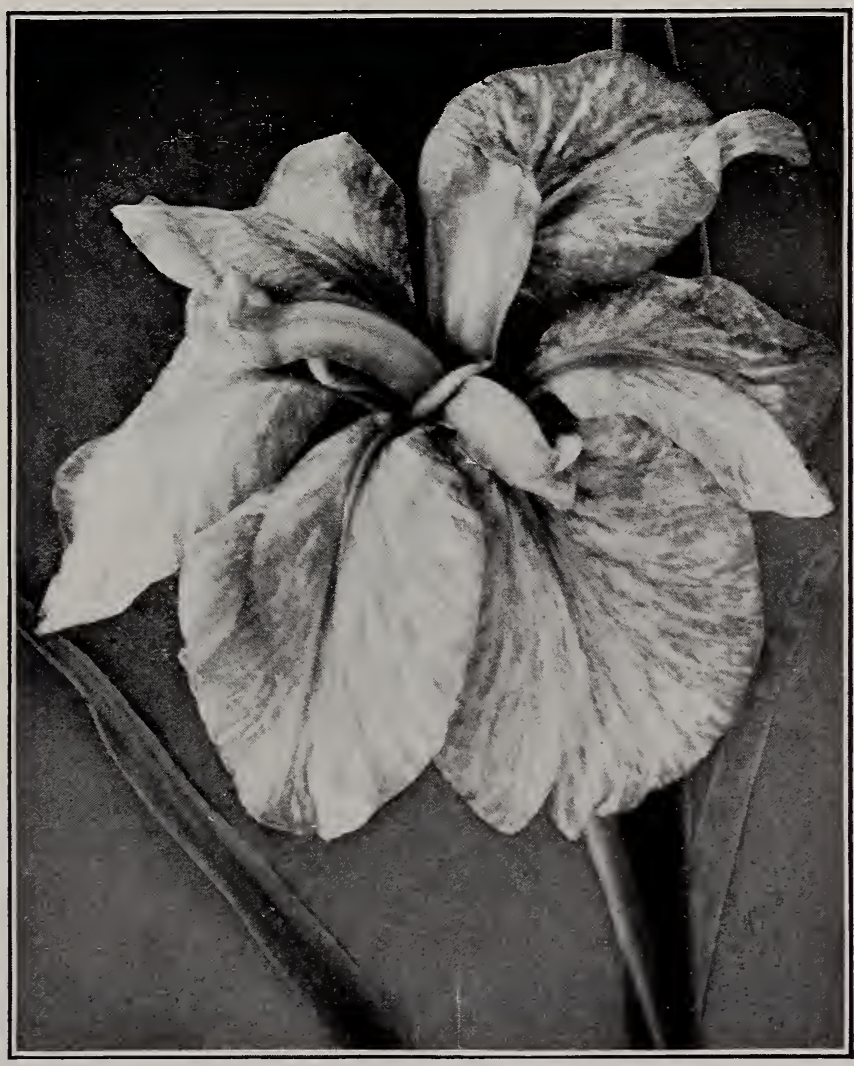

J APANESE IRIS 


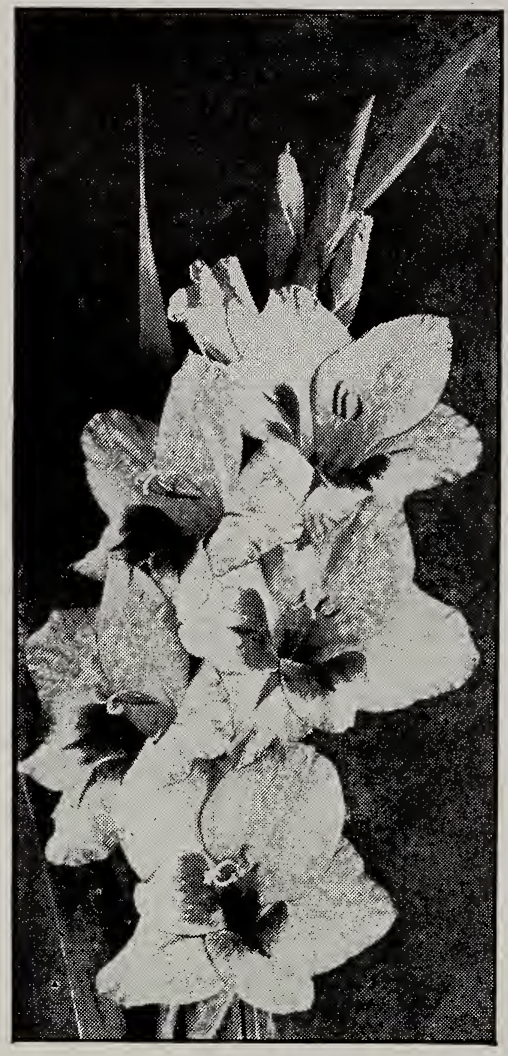

GLADIOLUS

CALLA LILIES. I grow a superfine quality of Callas at I $_{5}$ cts. each, \$r.50 per doz.

Hastata. The yellow, or Spotted Calla. Unlike the common Calla this grows flowers in the summer, and can be grown in cold climates if lifted in the fall when ripe. The leaves are spotted with white and the handsome flowers are light creamy yellow. ro cts. each, \$I per doz.

CHIONODOXA Luciliae. Glory of the Snow. A pretty, early, bulbous plant with light blue flowers. 30 cts. per doz. for large bulbs.

To have a fine display of flowers in the garden in early spring, provide for it in the fall.

\section{GLADIOLUS, CLASS II}

These are the large garden Gladioli and in California can either be left in the ground, planted in the fall, or in the spring. I prefer to do both, planting some in the fall, others at intervals in the spring until late June, and thus having fine flowers until fall.

My bulbs are a superfine mixture of Childsii and Groff's Silver Trophy Collection and will give satisfaction. 4 cts. each, 40 cts. per doz., $\$ 3$ per roo. Named sorts on application.

\section{VARIOUS BULBS FOR FALL PLANTING}

ALSTROEMERIA aurantiaca. A bulbous plant nearly related to gladiolus with very showy orange and yellow flowers borne well above the leaves on stout stems and much like a lily. Very easily grown in California and can be left in well-drained ground from year to year. Sun preferred. Io cts. each, \$I per doz.

CROCUS. Most pleasing very early flowers with grass-like leaves. They do fairly in shade in California but I have not seen them successfully grown in grass. In any color separately such as white, dark blue, light blue, pink, etc., at I5 cts. per doz., 75 cts. per Ioo, $\$ 6$ per I,, 00 .

Mixed. I 2 cts. per doz., 60 cts. per Io० $\$ 4.50$ per $\mathrm{I}, \infty \mathrm{\infty}$.

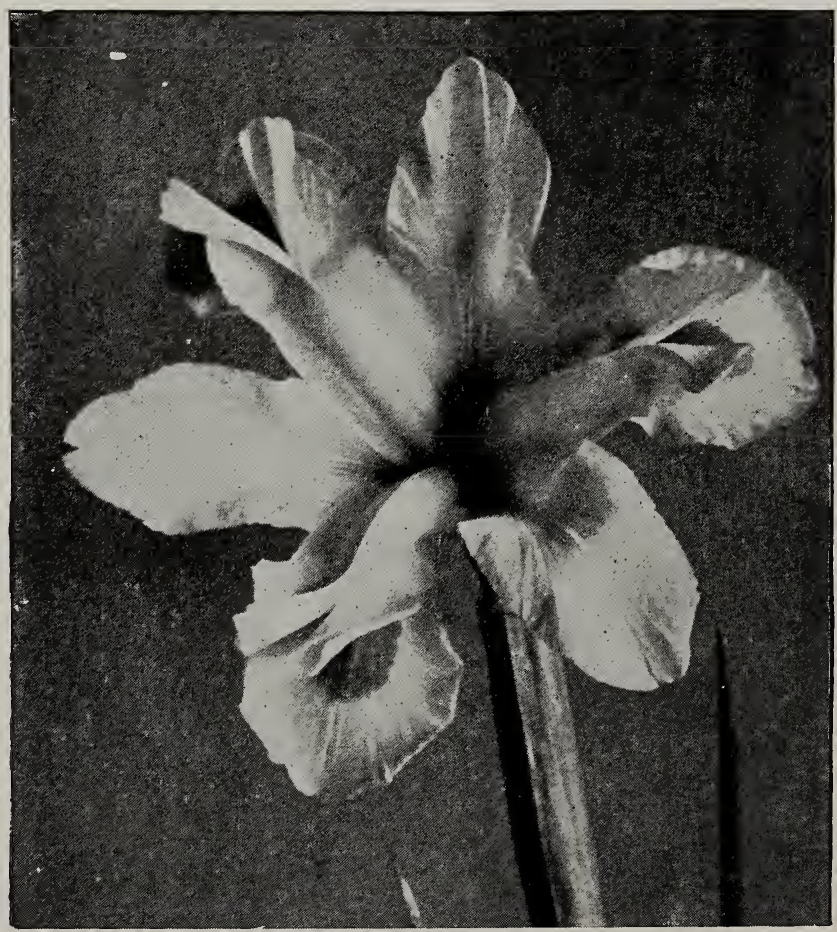

SPANISH IRIS (see page I 2) 
CYCLAMEN Persicum giganteum. I am able to offer very fine bulbs of this favorite house plant in white, dark red or rose-color at $20 \mathrm{cts}$. each, \$2 per doz.

Yellow and Papilio (marked like a butterfly). $30 \mathrm{cts}$. each, $\$ 3$ per doz.

DELPHINIUM. Perennial Larkspur. These splendid summer bloomers are unexcelled in showiness of bloom and length of flowering season. The spikes when well grown are from 4 to ro feet high, and in fine shades of blue, purple, white and light yellow. If cut when they have flowered out they will throw up new spikes and give a second bloom. Plant in any good garden soil in the sun. Feed well. See $3 \mathrm{~d}$ cover page.

Kelway's Seedlings. These are the best in Europe. In a mixture of many fine shades. I can not give these to color. Good plants Io cts. each, \$I per doz. I-year-old plants, I 5 cts. each, \$I.50 per doz.

Named English Varieties. In blues of any shade, purples, white and light yellow. Creamy white at $50 \mathrm{cts}$. each, other shades at $25 \mathrm{cts}$. each.

Nudicaule. A native of California and a fine orange-scarlet. Likes shade and a loose soil and very easily grown. \$I per doz.

HELLEBORE, or CHRISTMAS ROSES. These rare plants are related to Peonies and flower early as December with open flowers of good size in odd shades and very attractive. They stay in good shape for months during the winter. The leaves are rather pretty and they thrive in a shady place with good soil, preferring that rather heavy. I have had clumps as long as fifteen years without moving. They are well worth growing and will be noticed by every one who enters the garden. Named sorts 25 cts. each.

IXIAS. These are slender bulbous plants loving a warm situation and loose soil. In many fine colors. Mixed, 20 cts. per doz., $\$ 1.25$ per Ioo.

MONTBRETIAS. These are among the easiest of bulbs to grow in California whether in light or heavy soils, light shade or sunshine. They should be lifted and divided every year when they ripen, as they soon

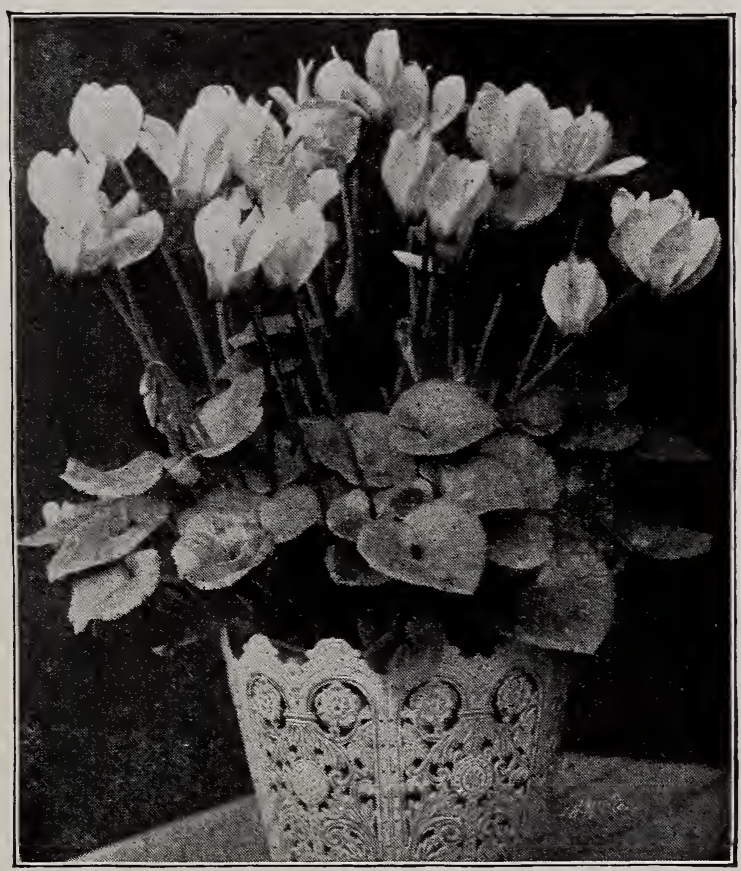

CYCLAMEN PERSICUM GIGANTEUM get too thick. The common sort is too well known to be sold, but I can offer good bulbs in ro named sorts, ro each, much showier than the common, at $\$ 3$ per roo.

MUSCARI plumosus (The Plume Hyacinth). Low-growing plants, with odd lilacpurple flowers, queerly cut into fine sprays. $3 \mathrm{cts}$. each, $25 \mathrm{cts}$. per doz.

Heavenly Blue. A dear little early flower with the bluest of blue blossoms. 3 cts. each, 25 cts. per doz.

ORNITHOGALUM Arabicum, or Star of Bethlehem. A bulbous plant with stem a foot or so high and a raceme of white flowers with black center; very pretty and early. 5 cts. each, 50 cts. per doz., $\$ 3$ per 100.

Umbellatum (Star of Bethlehem). A pretty, low-growing plant, with grassy leaves and pure white flowers. It can be turned out loose in open grass, or any odd corner, and will take care of itself. 3 cts. each, 25 cts. per doz.

PEONIES. These grand perennial plants will grow on in the same place and get better every year. They must have a heavy, rich soil, light shade and ordinary watering. The soil should be dug 2 feet deep, or more, and manure worked in liberally. Give a good manuring every year, but leave the clumps alone for years and you will be well rewarded for your trouble. The first year's bloom is poor.

Japanese Single and Double Varieties. Red, White and Pink. $25 \mathrm{cts}$. each, or twelve, no two alike, for $\$ 2$. Splendid European Varieties, all double, at the same price. 
RANUNCULUS. Stems 6 to Io inches high, bearing very bright, double flowers in all colors. Very pretty indeed. The soil must be very rich and loose and well watered, with very light shading. All colors mixed, I 5 cts. per doz., \$I per Ioo.

SCILLAS. Grassy leaved plants, with blue and pink racemes of graceful little flowers. They will take care of themselves in grass or any odd corner, and are worth while. In pink, blue and white, at 20 cts. per doz., \$ I per Io०.

SNOWDROPS. Dainty, low-growing bulbs, among the first to flower in spring. Of these, Elwesii is best. 20 cts. per doz., \$1.25 per Ioo.

SPARAXIS. Showy, low-growing bulbs related to the iris. Fine open flowers in many bright colors. They love a light, warm soil. $20 \mathrm{cts}$. per doz., \$r.50 per roo.

SPRING SNOWFLAKE. These are very much like immense Snowdrops; very graceful in growth with large flowers tipped with green. They should be grown in quantities for cutting. $3 \mathrm{cts}$. each, $30 \mathrm{cts}$. per doz., $\$ 2$ per roo.

TIGRIDIAS. Most showy summer-flowering bulbs. They must have a very light warm soil; sandy is better. Plant in spring and lift in fall when ripe. Few flowers are more brilliant. Six colors, $50 \mathrm{cts}$. per doz., for any of them.

TRITOMA Pfitzeri (Red-hot Poker). A most striking perennial plant, with long grassy leaves and a long, stout stem, tipped with a long mass of orange-scarlet flowers. A most showy plant and one that will stand endless neglect and grow in dry, hot places, yet which appreciates good treatment. $20 \mathrm{cts}$. each, $\$ 2$ per doz.

WATSONIAS. These very fine new bulbs are in the way of Gladioli but more refined in shape and color. The long spikes of pure white flowers are very satisfactory for any purpose. Plant like the gladiolus. I $5 \mathrm{cts}$. each, $\$ \mathrm{I} .50$ per doz.

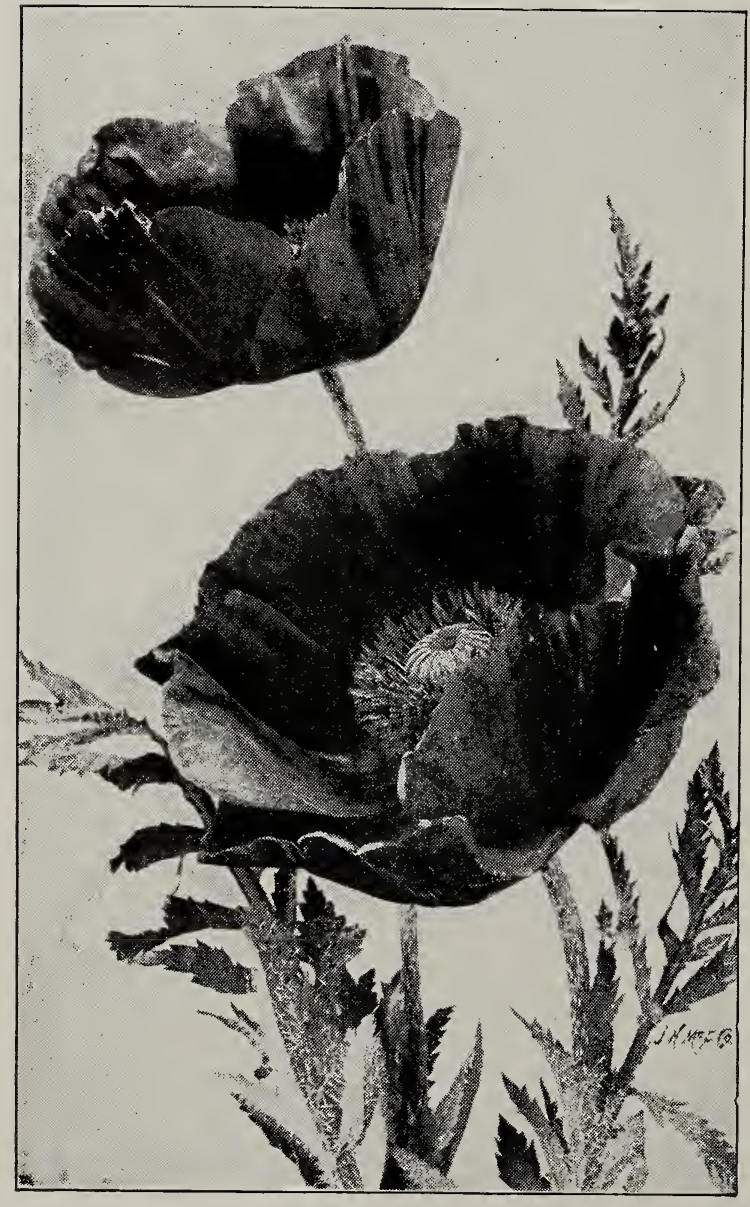

ORIFNTAL POPPIES

\section{ORIENTAL POPPIES}

The great orange-colored Oriental Poppy is becoming fairly well known, but very few people are aware that the same magnificent flower can be had in pink, glowing crimson and other shades of red. Flowers of immense size and the most brilliant of all Poppies. They are best planted in early autumn. I am importing roots this fall at the price of $25 \mathrm{cts}$. each, $\$ 2.50$ per doz., in any of the colors following: Nancy, Carmine-scarlet; Mrs. Perry, orange-apricot; Princess Ena, pale salmon-rose; Princess Victoria, soft salmon-rose; and Mary Studholme, salmon and carmine.

They must have a warm situation and a loose, deep soil is the best. I grow them ro inches across.

\section{LILIES}

For Californian Lilies and full descriptions and prices of the following, send for my catalogue of Californian bulbs.

Lilium candidum, tigrinum Fortunei, Thunbergianum, auratum, speciosum album, speciosum rubrum and longiflorum giganteum. 


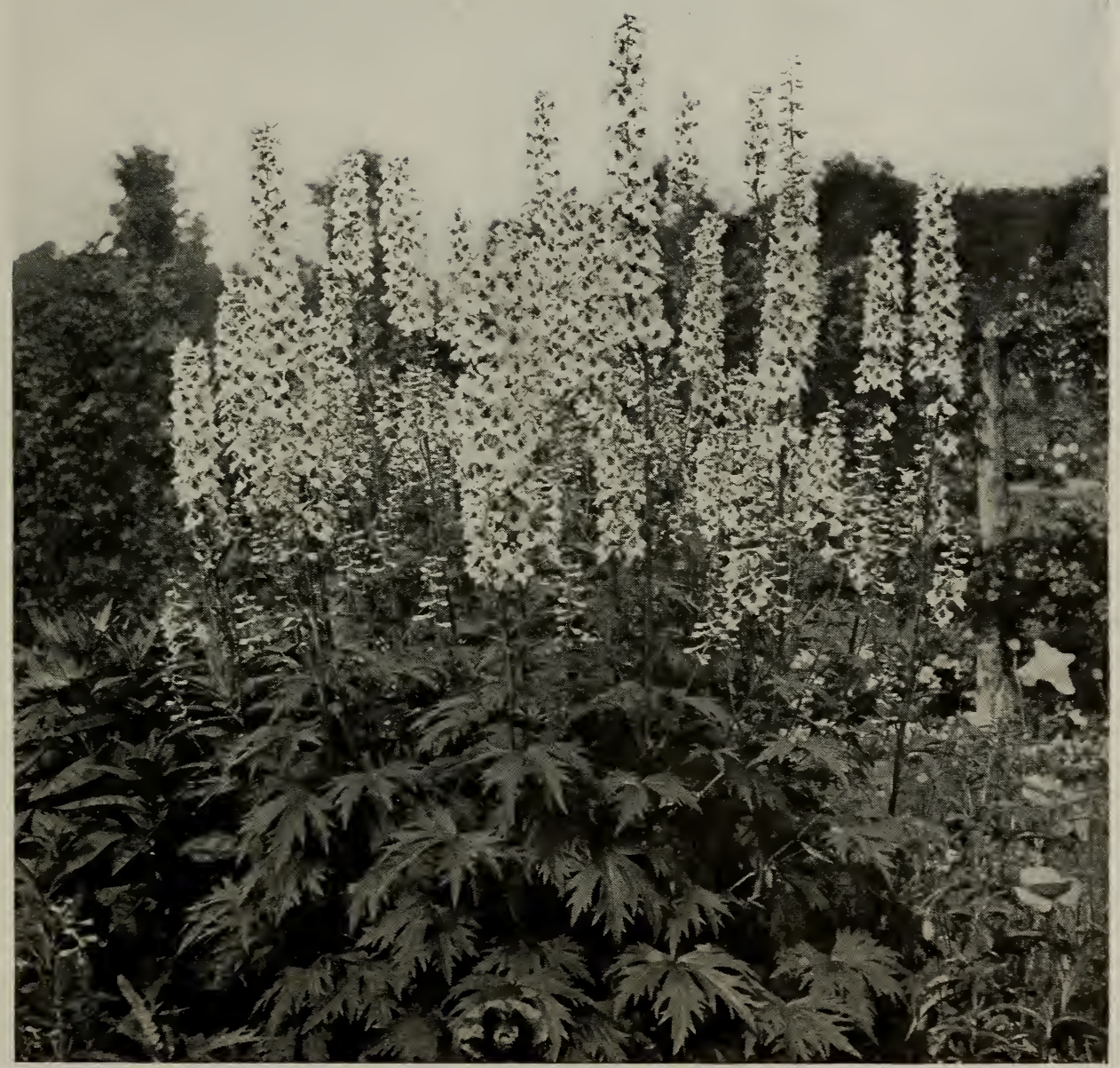

HARDY DELPHINIUMS (see page I5) 


\section{PURDY'S BULBS}

FOR FALL PLANTING

CARL PURDY

UKIAH, GALIFORNIA

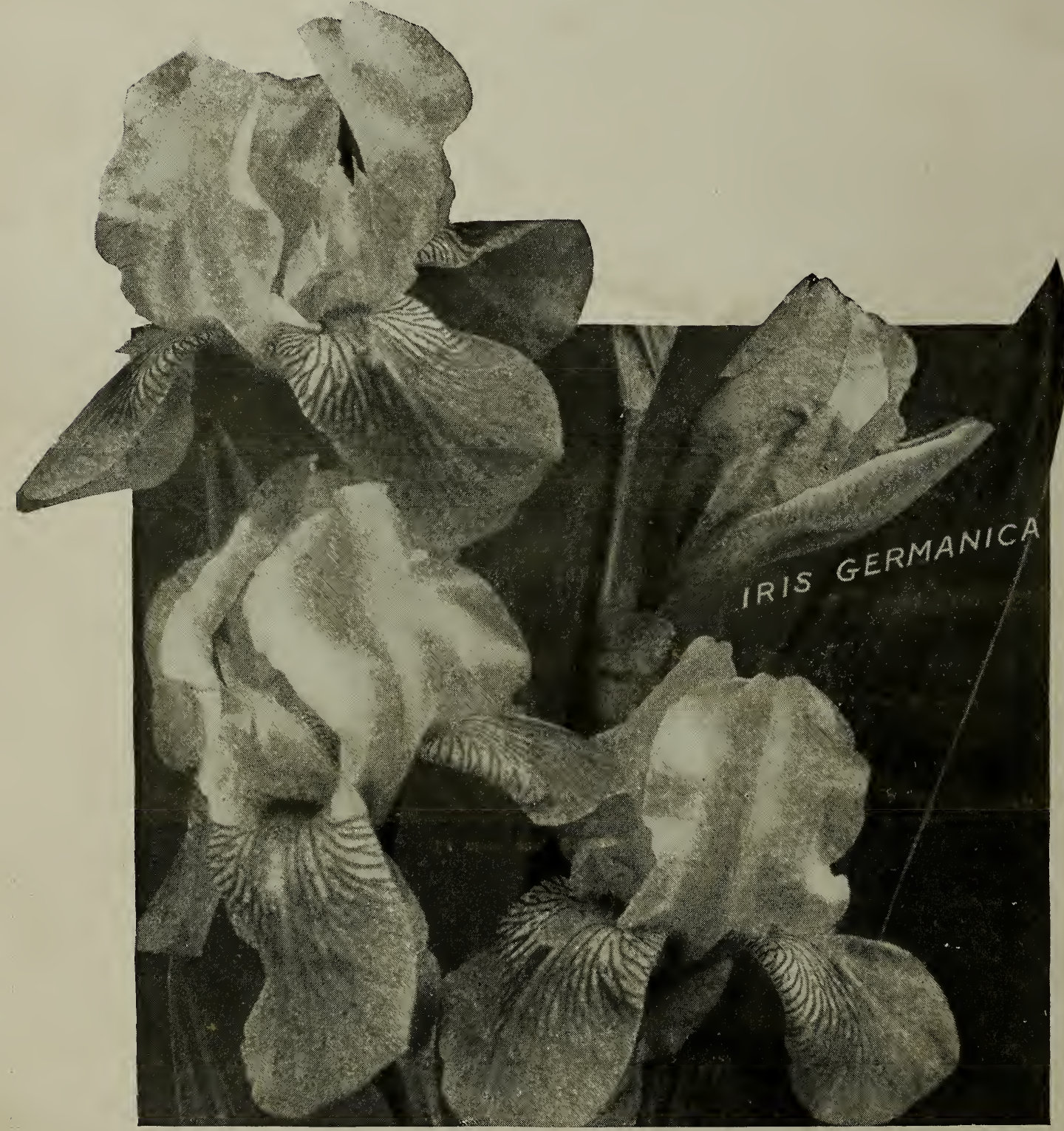

SEE PAGE I 2 